\title{
Hydrophysical properties of Humic Latosols from Brazil**
}

\author{
Ayodele Ebenezer Ajayi ${ }^{1,2,3 *}$, Moacir de Souza Dias Jr. ${ }^{1}$, Nilton Curi ${ }^{1}$, Paula Sant'Anna Moreira Pais ${ }^{1}$ \\ and Piero Iori ${ }^{1}$
}

\author{
${ }^{1}$ Department of Soil Science, Federal University of Lavras, Caixa Postal 3037, CEP:37200-000 Lavras MG, Brazil \\ ${ }^{2}$ Institute for Plant Nutrition and Soil Science, Christian-Albrechts-University Kiel, Olshausenstraße 40, 24118 Kiel, Germany \\ ${ }^{3}$ Department of Agricultural and Environmental Engineering, Federal University of Technology, \\ PMB 704, Akure, Ondo State, Nigeria
}

Received March 7, 2013; accepted July 8, 2013

\begin{abstract}
A b s t r a c t. The hydrophysical properties of the prevalent Humic Latosols (organic matter rich and charcoal stained soils) were related to structural sustainability under loading. Intact cores collected at the Ap, AB, Bw horizons were used for hydrophysical characterization. Precompression stresses at 10 suctions were obtained to estimate the load bearing capacities. We observed the dominance of kaolinite with some occurrences of gibbsite and hydroxy-interlayered vermiculite in the clay mineralogy. The high organic matter content in the Ap horizon favours crumb structure with the structural unit presenting high porosity and water retention. The structure of the $\mathrm{AB}$ and $\mathrm{Bw}$ horizons was, however, granular with structural units having low porosity. Possible influence of earlier incidences of fire enhanced the organic matter and carbon content in the soil reducing down the profile from $42.5 \mathrm{~g} \mathrm{~kg}^{-1}$ at the Ap to $16.4 \mathrm{~g} \mathrm{~kg}^{-1}$ at the Bw horizon. The $\mathrm{C} / \mathrm{N}$ ratio increased from 14 at the Ap to 17 at the $\mathrm{Bw}$, and air capacity increased from $18.1 \%$ at Ap to $32.0 \%$ at Bw. Precompression stress values were: $100.6 \pm 40.7 \mathrm{kPa}$ at $\mathrm{Ap}, 117.4 \pm 44.6 \mathrm{kPa}$ at $\mathrm{AB}$, and $116.1 \pm 58.9 \mathrm{kPa}$ at $\mathrm{Bw}$. Load bearing capacities at the $\mathrm{AB}$ and $\mathrm{Bw}$ horizons were homogenous.
\end{abstract}

K e y w o r d s: Humic Latosols, organic matter, precompression stress, hydrophysical properties

\section{INTRODUCTION}

In recent years, there is a growing interest in the understanding of the physicochemical processes of 'organic matter' rich soils regarding their significance in carbon sequestration and enhanced agronomic performance. These studies are often conducted with artificially amended soil. However, some unusual landscape processes in the tropics, particularly in Australia and Brazil, produced some 'naturally' carbon enriched soil that could assist in these studies. For example, periodic fires across the Australian landscapes

*Corresponding author e-mail: msouzadj@ufla.br

**This work was supported by the Brazilian Research Council (CNPq) for the Fellowship 300175/2011-6 from 2012 to 2013. resulted in a natural process of carbon sequestration from atmosphere to soil by the conversion of biomass to charcoal (Lehmann et al., 2008). Similarly, in the Brazilian landscape, the ancient agricultural management practices that created Terra Preta do Indio (deep black soils) were the precursor to biochar application in agriculture (Lehmann et al., 2008). Moreover, in the Brazilian landscape, there exist some well drained, fairly weathered soils with notably high levels of organic carbon (OC) covering approximately $144000 \mathrm{~km}^{2}$ and classified as Humic Latosol (HL) (Umbric Ferralsols - WRB, Ker, 1988; Marques et al., 2011).

Humic Latosols developed from gneiss of the precambrian complex, with an udic moisture regime and isothermic/ thermic regime and are generally dystrophic (Marques et al., 2011; Silva et al., 2007). The dystrophic condition and formerly prevailing mild temperatures inhibit microbial activity and favour the accumulation of organic matter. Their profiles are characterized by the development of a thick A horizon in a solum which is predominantly kaolinitic. Humic Latosols can be classified as Hydrol, Humic or LowHumic, depending on the ratios of the minerals: kaolinite, gibbsite, goethite, magnetite, mica, quartz, smectite and allophane in the sample (Sherman and Alexander, 1959). Humic Latosols contain substantial amounts of allophane (between 5 and 30\%) in their fine clay fraction, giving it a dark colour (chroma <4) (Embrapa, 2013). A pedo-geomorphological study and radiocarbon dating on four profiles of HL in Brazil revealed that the strongly developed umbric epipedons were very old and had a continuous and progressive melanization (a darkening process of the soil by addition of

(C) 2014 Institute of Agrophysics, Polish Academy of Sciences 
organic matter) with depth, which is strongly influenced by the decomposition and redistribution of charcoal fragments by soil fauna (Silva and Vidal-Torrado, 1999).

The marked content of soil organic matter in Humic Latosols makes it an important reservoir of organic carbon (Andrade et al., 2004; Fontana et al., 2008), thus requiring propermanagementtoforestalldegradation. Thisisimportant, considering that up till now the mechanism of accumulation and stabilisation of organic matter in Humic Latosols is not properly understood (Marques et al., 2011; Silva and Torrado, 1999). Humic Latosols are similar in physical properties to the Terra Preta do Indio soils of Brazil which hold large reserve of organic carbon (Lehmann et al., 2008). However, their formation processes and chemical properties are quite different. Whereas Terra Preta do Indio was formed primarily under human influence with uneven vertical and horizontal distribution of organic carbon, high phosphorus content (200-400 $\left.\mathrm{mg} \mathrm{kg}^{-1}\right)$ and cation exchange capacity dominated by $\mathrm{Ca}^{2+}$ and $\mathrm{Mg}^{2+}$, Humic Latosols are natural phenomenon (Novotny et al., 2009). The charcoal fragments occurring in the top slope and decreasing gradually in carbon content with depth are not associated with lithic artefacts or pieces of pottery. Humic Latosols has low concentrations of phosphorus and the exchange complex is dominated by $\mathrm{Al}^{3+}$ (Ker, 1997; Marques et al., 2011).

Humic Latosols are relatively fertile and well cultivated in the Brazilian mechanized agriculture system for the production of eucalyptus, coffee, and soybean (Marques et al., 2011). However, the elevated organic matter and clay content associated with all types of Humic Latosols implies higher susceptibility to shearing and compaction amongst other forms of degradation under mechanized agriculture. Compaction will degrade the soil structure and negatively alter the pore geometry and functions. These alterations affect the soil quality and impact negatively the environment in terms of $\mathrm{CO}_{2}$ emissions and carbon sequestration (Parfitt et al., 1997). Moreover, it has been reported that organic matter decomposition due to land conversion for agriculture is a major driver of climate change (Watson et al., 2000). It is therefore presumed that adequate understanding of the physical processes relating to the accumulation and stabilisation of organic matter in Humic Latosols would contribute to a better understanding of the carbon cycle (Calegari, 2008; Marques et al., 2011).

Land conversion in mechanized agriculture generally decreases the size of the soil aggregate. Additionally, the organic matter would decrease and the free Fe oxides in the converted land would increase, while the aggregation of soil particle decreases (Teh Boon Sung, 2012). The implication of this on the structure of Humic Latosols may be damaging and there has been no study that determines the intrinsic strength of Humic Latosols, despite their increased cultivation under mechanized agriculture in Brazil. Similarly, the structural configuration of Humic Latosols is important in carbon sequestration potential. Thus our objectives in this study were to characterize the hydrophysical behaviour of typic Humic Latosols from Brazil, evaluate the stressstrain responses at different matric potentials, and estimate the load bearing capacity for different horizons.

\section{MATERIALS AND METHODS}

Working with detailed classification and characterization of the prevalent Humic Latosols found in Brazil by Calegari (2008) and Marques et al. (2011), we selected a representative sampling site with high proportion of clay particles within Minas Gerais State, Brazil. At the site, intact soil cores were collected in $6.5 \times 2.5 \mathrm{~cm}$ rings in the Ap $(0-10 \mathrm{~cm}), \mathrm{AB}(60-80 \mathrm{~cm})$ the A-B horizon transition, and in the Bw (100-120 cm) horizon. At each horizon, 45 samples were collected by carefully pushing the rings into the soil using Uhland sampling device. The ring filled with soil was removed from the sampler and wrapped in plastic materials and waxed to preserve the structure during transport to the laboratory.

In the laboratory, the soil samples were carefully trimmed to the size of their rings, to determine the field bulk density. Scraped samples near the intact soil cores were airdried, passed through a $2 \mathrm{~mm}$ sieve to do standard physical and chemical characterization of the studied soils following the standard procedures used in Brazilian laboratories as described in Embrapa (1997). Particle size distribution was determined using the pipette method after dispersing with $1 \mathrm{~mol} \mathrm{l}^{-1} \mathrm{NaOH}$, and shaken in motorized agitator end-overend for $24 \mathrm{~h}$. Water dispersible clay (WDC) was determined in the same way as particle size using $\mathrm{H}_{2} \mathrm{O}$ instead of $\mathrm{NaOH}$. The clay dispersion ratio $(C D R)$ was calculated as:

$$
C D R=\frac{W D C\left(\mathrm{~g} \mathrm{gg}^{-1}\right)}{T C\left(\mathrm{~g} \mathrm{gg}^{1}\right)},
$$

and the clay flocculation index $(C F I)$ was computed as:

$$
C F I=\frac{T C-W D C}{T C}
$$

Particle density was determined using 95\% hydrated alcohol with $20 \mathrm{~g}$ of oven-dried soil material in a $50 \mathrm{ml}$ pycnometer. Total porosity (TP), air capacity (AC), and other pore parameters were calculated according to Hartge and Horn (2009) from the water retention data. Organic carbon (OC) was determined using the wet combustion method. The aggregate stability index (ASI) was established by screening in water, with a set of 2, 1, 0.5, 0.25 and $0.105 \mathrm{~mm}$ sieves, and the geometric mean diameter of aggregates (GMD) was determined following the procedure of Sutherland and Ziegler (1997). The stability index (SI), which indicates the level of organic matter required to maintain the structure, was obtained based on the expression: 


$$
\mathrm{SI}=(\mathrm{OM}(\mathrm{C}+\mathrm{S})-1) 100
$$

where: SI - stability index (\%), C - clay content (\%), S - silt content $(\%)$, and $\mathrm{OM}-$ organic matter content $(\%)$. We determined $\mathrm{Si}, \mathrm{Al}, \mathrm{Fe}$, Ti and $\mathrm{Mn}$ after digestion with $9.4 \mathrm{~mol} \mathrm{l}^{-1}$ $\mathrm{H}_{2} \mathrm{SO}_{4}$. Gibbsite $(\mathrm{Gb})$ and kaolinite $(\mathrm{Ka})$ contents were determined in the iron-free clay fraction, while goethite (Gt)and hematite $(\mathrm{Hm})$ contents were determined in the iron-concentrated clay fraction according to Kampf and Schwertmann (1982). X-ray diffractograms of the clay fraction were obtained using a Philips diffractometer, with CoK $\alpha$ radiation and Fe filter. The non-oriented slides were scanned from 4 to $50^{\circ} 2 \theta$, using $0.02^{\circ} 2 \theta$ steps and $1 \mathrm{~s}$ counting time per step.

Water retention at the studied horizons was characterized using intact samples in replicates, desiccated to $-1,-2$, $-4,-6,-8,-10,-33,-100,-500$ and $-1500 \mathrm{kPa}$ after initial saturation by capillary. The water content was obtained gravimetrically by drying the samples at $105^{\circ} \mathrm{C}$ for $48 \mathrm{~h}$. Uni-axial compression test was implemented at these suctions using a pneumatic S-450 Terraload floating ring consolidometer (Durham Geo Enterprises, USA). For the test, the sample held within the coring cylinder and placed in compression cell was submitted to vertical pressures of $25,50,100,200,400,800$ and $1600 \mathrm{kPa}$ in steps. Each pressure step was applied until the sample compressed and came to equilibrium. At this point, there would be little or no further deformation in the sample and the excess pore water pressure within the sample was approximately equal to zero. Thus, the final or equilibrium stress was the effective stress (Holz and Kavaz, 1981). To establish the relationship between the applied load and deformation in the sample during the compression test, the deformation rate in form of dial reading was assessed at elapsed times of $0.25 .0 .5,1,2,4,8,15,30,120$ min or stopped when $90 \%$ of the maximum deformation was reached (Ajayi et al., 2013). For tropical soils, it has been established that the $90 \%$ of the maximum deformation of soil sample is attained at about $15 \mathrm{~min}$ in partially saturated condition (Dias Jr., 2003). Free drainage was ensured by sinter metal plates beneath and above the soil samples. The final water content of each sample was determined by oven-drying at $105-110^{\circ} \mathrm{C}$ for $24 \mathrm{~h}$. The stress versus strain data were used to construct the soil compression curves for the measured suctions and the precompression stress $\left(\sigma_{p}\right)$ was determined following the procedure of Dias Jr. and Pierce (1995).

\section{RESULTS AND DISCUSSION}

The studied Humic Latosols were slightly acidic at the 3 horizons with the $\mathrm{pH}$ (in water) declining from 5.1 at the Ap -horizon to 4.7 in the Bw-horizon. This is consistent with the behaviour of Latosols. The organic carbon, total carbon concentration and cation exchange capacity (CEC) were the highest in the Ap horizon, decreas- ing down the profile (Table 1). The low range of CEC in Latosols had been related with the presence of low activity clay, kaolinite and oxides (Tawornpruek et al., 2006). The CEC as observed here is not directly related to soil organic matter concentration, since much of the exchange capacity in these soils is due to kaolinite (Hart et al., 2003) and many exchange sites on the organic matter are occupied by $\left[\mathrm{Al}^{3+}\right]$ which is not readily exchanged (Schnitzer, 1986; Tawornpruek et al., 2006).

The texture at the sampled horizons was clay with very low silt content. Bulk density $(B D)$ values ranged from 1.19 to $1.28 \mathrm{Mg} \mathrm{m}^{-3}$. The values are in the median range of the $0.7-1.7 \mathrm{Mg} \mathrm{m}^{-3}$ bulk density observed in Latosols types found in Brazil (Ajayi et al., 2009). The bulk densities of the Latosols types have been related to the proportion of iron oxides or gibbsite which influences the arrangement of the kaolinite plates either into blocky or granular structure (Ajayi et al., 2009; Severiano et al., 2013). The particle density ranged from 2.30 to $2.44 \mathrm{~kg} \mathrm{dm}^{-3}$, while the packing density ranged from 1.68 to $1.70 \mathrm{Mg} \mathrm{m}^{-3}$. The packing density, though not commonly used in agricultural soil mechanics, gives a clue to the arrangement in packs of the soil particles and aggregates. It is computed as:

$$
P D=B D_{d}+0.0009 \mathrm{C},
$$

where: $B D_{d}$ is the dry bulk density and $\mathrm{C}$ is the clay content (Jones et al., 2003). The packing density results showed that Humic Latosols are moderately packed along the profile in a uniform manner. The values were higher than the average for most variants of Latosols in Brazil (Ajayi et al., 2009), possibly due to the level of organic carbon in the soil matrix. The particle density values were lower than the average $2.65 \mathrm{Mg} \mathrm{m}^{-3}$ used for mineral soils.

The clay-dispersion ratio $(C D R)$ and water dispersible clay $(W D C)$ were very high in the Ap and $\mathrm{AB}$ horizons, indicating a likelihood of high erodibility at the thick epipedon that characterizes humic Latosols (Igwe, 2005; Marques et al., 2011), therefore adequate management is essential to maintain HL when cultivated. This observation contrast the suggestion of high micro-aggregates stability resulting from the cementing action of $\mathrm{OM}$ and aggregation action of $\mathrm{Fe}$ and $\mathrm{Al}$ oxides, particularly in clayey soils (Donagemma et al., 2003). Both indices were very low in the Bw-horizon, possibly due to smaller content of $\mathrm{OM}$ in both the $\mathrm{Fe}$ and $\mathrm{Al}$ oxides at this horizon. This difference in the behaviour of the clay fraction in water between the A and B horizons was similarly observed by Nguetnkam and Dultz (2012) in a study on Oxisols in Central North Cameroon. In a study on Ultisols in a tropical catchment, WDC was observed to be influenced by the several factors including $\mathrm{pH}$, soil organic carbon and CEC (Igwe and Udegbunam, 2008). We did not notice any distinct influence of these parameters on the measured WDC. A study by Józefaciuk et al. (1995) had similarly shown that the total 
and divalent iron contents, surface area and average adsorption energies of water dispersible clay were complicated functions of the $\mathrm{pH}$. The relationship reflects the simultaneous effect of mineral destruction and aggregate disruption processes under the influence of protons on soils.

The XRD (not presented) showed the dominance of kaolinite over gibbsite and the presence of hydroxy-interlayered vermiculite (HIV) in the clay mineralogy. It would therefore be expected that Humic Latosols would only shrink and swell minimally. Moreover, the prevalence of organic matter would hinder the formation of a blocky structure by the kaolinite sheets, thereby favouring a crumb structure in the Ap-horizon (Resende et al., 2014). This structure contributes to the observed low bulk density which makes Humic Latosols particularly susceptible to compaction. The occurrence of HIV has been reported in some Latosols in Brazil (Ker, 1997). Although not measured, charcoal fragments were observed to be scattered in the soil matrix suggesting that, in addition to other formation factors, natural fires, charcoal fragments decomposition and redistribution by soil fauna in former times possibly played an important role in the pedogenesis of some of the Humic Latosols of Brazil (Marques et al., 2011; Tomasi et al., 2012), similar to the chernozemic soils in Germany (Schmidt et al., 1999) and volcanic ash-rich soils in Japan (Shindo et al., 2004).

Humic Latosols retain water very well along their profile with more water retained at the Bw-horizon (Fig. 1). This may be attributable to the prevalence of clay particles, organic matter levels and the previously noted occurrence of HIV in the clay mineralogy (Martin et al., 1998). The presence of HIV in the clay mineralogy affects the available adsorption sites between the mineral layers, thereby enhancing water retention (Ajayi et al., 2013). The adequate water retention behaviour apparently makes the soil more productive in agriculture and forestry, but more susceptible to compaction in mechanised agriculture, if the soil is moist or wet at preparation epoch.

The precompression stress values obtained for the samples at various suctions between near saturation $(0 \mathrm{kPa})$ and permanent wilting point $(-1500 \mathrm{kPa})$ are presented radially in Fig. 2. Similar to observations in several previous studies (Iori et al., 2013), the precompression stress increases as the water dries out, indicating that the internal bonding force between the soil particles weakens as the water level in the soil increases (Horn et al., 2004). Although there is no clear trend in terms of which of the horizons have the highest precompression stress, it does appear that at suction level critical in agriculture (- $10 \mathrm{kPa}$ to $-100 \mathrm{kPa})$ the $\mathrm{Bw}$-horizon had higher values of precompression stresses, while the Ap-horizon had the lowest values. To appreciably understand the distribution of the measured precompression stresses at the various horizons, a box plot (Fig. 1b) was prepared. This clearly described the magnitude of variation in the $\mathrm{Bw}$ horizon while showing the median values of the precompression stress were slightly higher in the $\mathrm{AB}$, transition zone, and lowest at the topsoil, Ap. Since the precompression stress reflects the pedogenetic processes and anthropogenic effects (Horn et al., 2004) and the maxi-

T a b l e 1. Characteristics and behaviour of the Humic Latosols (HL) at the studied horizons

\begin{tabular}{|c|c|c|c|}
\hline \multirow{2}{*}{ Parameter } & \multicolumn{3}{|c|}{ Horizon } \\
\hline & Ap & $\mathrm{AB}$ & $\mathrm{Bw}$ \\
\hline Clay $\left(\mathrm{g} \mathrm{kg}^{-1}\right)$ & 660 & 690 & 710 \\
\hline Sand $\left(\mathrm{g} \mathrm{kg}^{-1}\right)$ & 300 & 280 & 280 \\
\hline Silt $\left(\mathrm{g} \mathrm{kg}^{-1}\right)$ & 40 & 30 & 10 \\
\hline $\operatorname{CECe}\left(\mathrm{cmol}_{\mathrm{c}} \mathrm{dm}^{-3}\right)$ & 2.27 & 1.19 & 1.07 \\
\hline $\mathrm{pH}_{\text {water }}$ & 5.15 & 4.80 & 4.70 \\
\hline $\begin{array}{l}\text { Particle density } \\
\left(\mathrm{kg} \mathrm{dm}^{-3}\right)\end{array}$ & 2.44 & 2.30 & 2.38 \\
\hline WDC $\left(\mathrm{g} \mathrm{kg}^{-1}\right)$ & 468.5 & 490.1 & 65.4 \\
\hline CDR & 0.710 & 0.710 & 0.092 \\
\hline CFI & 0.290 & 0.290 & 0.908 \\
\hline Stability index & 4.6 & 7.9 & 10.7 \\
\hline Total pore volume $(\%)$ & 56.59 & 53.34 & 62.33 \\
\hline Air capacity $(\%)$ & 18.12 & 16.64 & 32.04 \\
\hline Field capacity $(\%)$ & 38.47 & 39.92 & 30.29 \\
\hline Total water (\%) & 21.44 & 22.50 & 22.45 \\
\hline Organic carbon $\left(\mathrm{g} \mathrm{kg}^{-1}\right)$ & 42.5 & 17.5 & 16.4 \\
\hline Total carbon $\left(\mathrm{g} \mathrm{kg}^{-1}\right)$ & 55.7 & 22.8 & 18.7 \\
\hline Nitrogen & 3.9 & 1.5 & 1.1 \\
\hline $\mathrm{CEC}_{\mathrm{pH} 7}\left(\mathrm{cmol}_{\mathrm{c}} \mathrm{dm}^{-3}\right)$ & 8.46 & 6.59 & 5.61 \\
\hline Packing density & 1.70 & 1.67 & 1.68 \\
\hline Bulk density $\left(\mathrm{Mg} \mathrm{m}^{-3}\right)$ & 1.28 & 1.22 & 1.19 \\
\hline Plastic limit (\%) & 0.27 & 0.32 & 0.31 \\
\hline Liquid limit (\%) & 0.51 & 0.48 & 0.58 \\
\hline C/N Ratio & 14 & 15 & 17 \\
\hline GMD $(\mathrm{mm})$ & 3.59 & 3.83 & 3.91 \\
\hline Wide coarse pores $(\%)$ & 32.02 & 30.78 & 51.44 \\
\hline Narrow coarse pores $(\%)$ & 20.53 & 17.53 & 4.22 \\
\hline Medium pore $(\%)$ & 9.56 & 9.51 & 8.35 \\
\hline Fine pores $(\%)$ & 37.89 & 42.18 & 36.02 \\
\hline
\end{tabular}


mum vertical overburden stress that the soil has sustained in the past (Holtz and Kovacs, 1981), the magnitude of variation in the $\mathrm{AB}$ and $\mathrm{Bw}$ horizons, though unexpected, may be related to differential pedogenetic activities at this layer. The relatively higher precompression stress values in the $\mathrm{Bw}$ horizon is consistent with some previous studies on another variety of Latosols at this horizon in Brazil (Ajayi et $a l ., 2009$ ) and had been shown to be lower than the critical strength for root elongation (Römkens and Miller, 1971). Thus, the development of deep-rooted plants will be unhindered in Humic Latosols. Comparing the range of values of the precompression stresses obtained, Humic Latosols are intermediate between the blocky and granular structured Latosols. Latosols structure is strongly influenced by the clay mineralogy and oxide contents (Ajayi et al., 2009).
Kaolinitic Latosols with high amount of iron oxides and no gibbsite form blocky structure resulting in high precompression stress values, while gibbsitic Latosols are granular in structure and have low precompression stress values.

Precompression stress, when measured at different water content or suction, is a useful indication of the sample internal strength (Pais et al., 2013) but does not provide sufficient information for decision making in agriculture and forestry operations, since soil water varies over very short time span. We therefore estimated the load bearing capacity (LBC) of the Humic Latosols at the studied horizon from the measured precompression stress values at various suctions. The LBC provides a better insight into the variation of the soil internal strength with water contents (Fig. 2a),

b

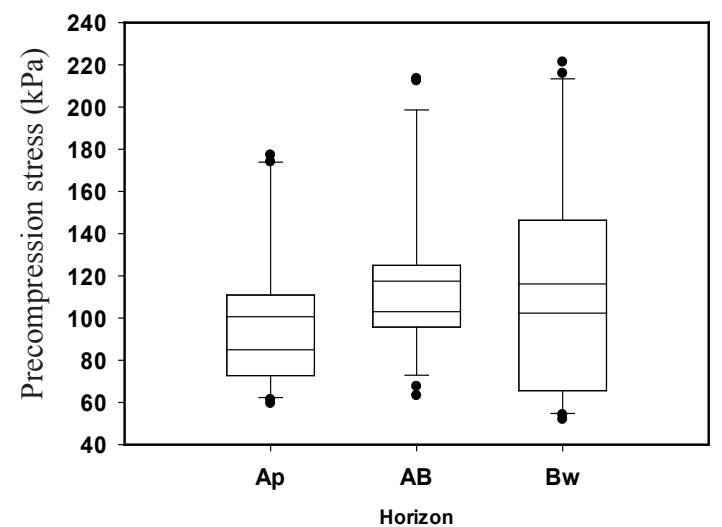

Fig. 1. Water retention (a) and distribution of the precompression stress (b) at the 3 horizons studied.

a

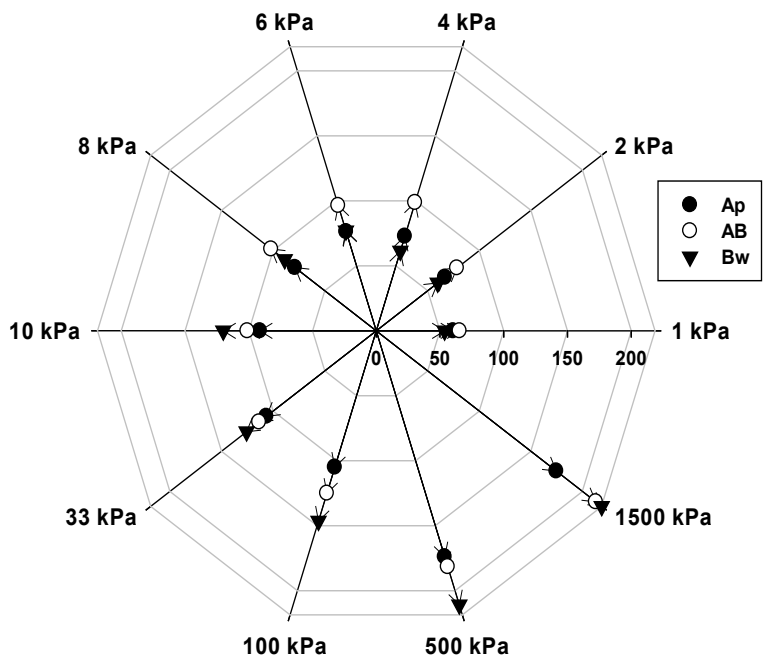

b

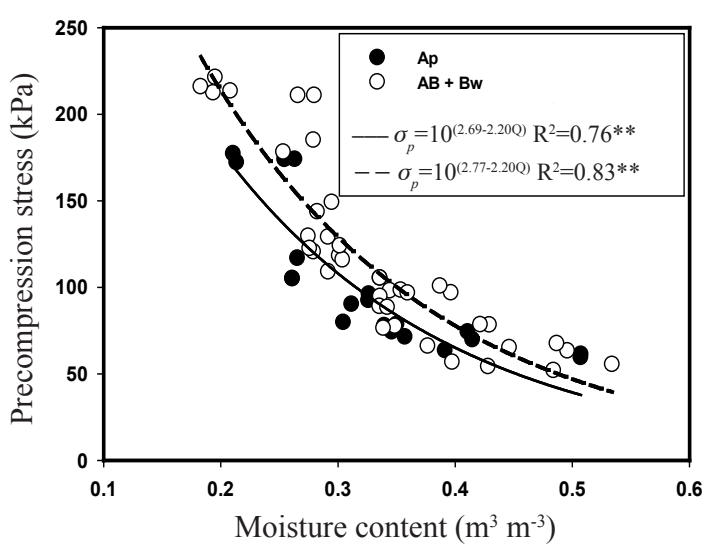

Fig. 2. Variation in precompression stresses with suction (a) and load bearing capacity equations after statistical comparison (b). 
T a b l e 2. Statistical comparison of the load bearing capacity equations at the studied horizons

\begin{tabular}{|c|c|c|c|c|c|c|}
\hline \multirow{3}{*}{ Horizon } & \multirow{2}{*}{\multicolumn{2}{|c|}{$\mathrm{F}$}} & \multicolumn{4}{|c|}{$\mathrm{F}$} \\
\hline & & & \multicolumn{2}{|c|}{ Angular coefficient, b } & \multicolumn{2}{|c|}{ Intercept of regression, a } \\
\hline & $5 \%$ & $1 \%$ & $5 \%$ & $1 \%$ & $5 \%$ & $1 \%$ \\
\hline Ap $v s . \mathrm{Bw}$ & $\mathrm{H}$ & $\mathrm{H}$ & NS & NS & $*$ & $* *$ \\
\hline Ap $v s . \mathrm{AB}$ & $\mathrm{NH}$ & $\mathrm{H}$ & NS & NS & $*$ & $* *$ \\
\hline $\mathrm{Bw} v s . \mathrm{AB}$ & $\mathrm{H}$ & $\mathrm{H}$ & NS & NS & NS & NS \\
\hline
\end{tabular}

$\mathrm{H}$ - homogenous, $\mathrm{NH}$ - not homogenous, $\mathrm{NS}$ - not significant.

and describe the capability of the soil structure to withstand stresses induced by field traffic without changes in the threedimensional arrangement of its constituent soil particles (Alakukku et al., 2003). The Ap horizon had the lowest capacity at all water contents compared to the $\mathrm{AB}$ and $\mathrm{Bw}$ horizons. This indicates that the Ap horizon is more susceptible to compaction if stresses higher than the precompression stress are applied by agricultural machinery. It is noteworthy that, at the water range of 0.2 and $0.4 \mathrm{~m}^{3} \mathrm{~m}^{-3}$ where most field operations are carried out, the maximum capacity in the horizons was below $150 \mathrm{kPa}$, particularly in the Ap horizon, highlighting the vulnerability of Humic Latosols to compaction and the associated degradation (Dias Jr. et al., 2005).

To examine possible differences in the in $\mathrm{LBC}$ at the different horizons, we implemented the Snedecor and Cocharan (1989) procedure to test for homogeneity of the LBC equation parameters. In the procedure, two equations are picked and compared together by examining the intercept ' $a$ ', slope ' $b$ ' and the homogeneity parameter data (F). To obtain ' $a$ ' and ' $b$ ' values in each LBC equation for comparison, the $\mathrm{LBC}$ equation in the exponential form $\left(\sigma_{p}=10^{(a+b \theta)}\right)$ was transformed into a linear model by obtaining the logarithm of both sides of the equation, giving an equation of the form:

$$
\log \left(\sigma_{p}\right)=\log \left(10^{(a+b \theta)}\right) \leftrightarrow \log \sigma_{p}=a+b \theta
$$

(Dias Jr. et al., 2005). The results presented in Table 2 indicated that the $\mathrm{LBC}$ data for the Ap and $\mathrm{Bw}$ horizons were homogenous but there were significant differences in the parameter ' $a$ ' the intercept of the regression lines at both 5 and $1 \%$ levels. Similarly, when the LBC for the Ap and AB horizons were compared, we observed significant differences in the ' $\mathrm{a}$ ' parameter and the LBC data were not homogenous at $5 \%$. However, when the LBC equations of $\mathrm{AB}$ and $\mathrm{Bw}$ horizons were compared, there were no significant differences in all the LBC parameters and the data were statistically homogenous at all levels. This imply that the $\mathrm{LBC}$ for the $\mathrm{Bw}$ and $\mathrm{AB}$ horizons were statistically similar but different from that the Ap horizon. A representative
$\mathrm{LBC}$ for $\mathrm{AB}$ and $\mathrm{Bw}$ horizons was then constructed by pooling their data together (Fig. 2b). The fitted parameter 'a' was related to the packing state of the solid particles expressed by soil bulk density and air-filled porosity which affect the pore water pressure, while the parameter ' $b$ ' is influenced by soil properties such as texture and organic matter content (Peng et al., 2004). Our results in this study further suggest that the parameter ' $a$ ' is better related to the packing density of the soil (influenced by pedogenetic processes) which influences the intrinsic strength of the dry soil, while the parameter ' $b$ ' reflects the textural properties which influence water retention.

\section{CONCLUSIONS}

1. Water retention is high at all suctions and in all studied horizons of Humic Latosols.

2. Load bearing capacity of studied soil is low, implying higher susceptibility to compaction.

3. Parameter ' $a$ ' of the Load Bearing Capacity equation is dependent on the packing state of the soil, better expressed by the packing density, whereas the parameter ' $b$ ' depends on the texture and influences the water retention.

4. Bulk density and precompression stress are intermediate between the Kaolinitic Latosols (high) and Gibsitic Latosols (low), which is related to their differential structure.

5. Organic carbon contents of Humic Latosols are high and do not decrease exponentially with depth, thus will be a good target for mechanized agriculture.

\section{REFERENCES}

Ajayi A.E., Dias Jr. M.S., Curi N., Araujo Jr. C.F., Teixeira Souza T.T., and Inda Jr. A.V., 2009. Strength attributes and compaction susceptibility of Brazilian Latosols. Soil Till. Res., 105, 122-127.

Ajayi A.E., Dias Jr. M.S., Curi N., and Oladipo I., 2013. Compressive response of some agricultural soils influenced by the mineralogy and moisture. Int. Agrophys., 27, 239-246.

Alakukku L., Weisskopf P., Chamen W.C.T., Tijink F.G.J., van der Linden J.P., Pires S., Sommer C., and Spoor G., 2003. Prevention strategies for field traffic-induced subsoil compaction: a review. Part 1. Machines/soil interactions. Soil Till. Res., 73, 1/2, 145-160. 
Andrade F.V., Schaefer C.E.G.R., Correa M.L.T., and Mendonca E.S., 2004. Carbon stocks in Brazilian Latosols (oxisols) from different morphoclimatic regions and management systems. Communications Soil Sci. Plant Analysis, 35, 15-16.

Calegari M.R., 2008. Occurrence and paleo-environmental significance the humic Oxisols horizon. Piracicaba Superior School of Agriculture, Piracicaba, Brazil.

Dias Jr. M.S., 2003. A soil mechanics approach study soil compaction In: ACHYUTHAN H (ed) Soil and soil physics in continental environment. Chenna: Allied Publishers Private, 179-199.

Dias Jr. M.S., Leite P.F., Lasmar Jr. E., and Araújo Jr. C.F., 2005. Traffic effects on the soil preconsolidation pressure due to eucalyptus harvest operations. Sci. Agric., 62, 248-255.

Dias Jr. M.S. and Pierce F.J., 1995. A simple procedure for estimating preconsolidation pressure from soil compression curves. Soil Technol., 8, 139-151.

Donagemma G.K., Ruiz H.A., Fontes M.P.F., Ker J.C., and Schaefer C.H.G.R., 2003. Dispersion of Oxisols in response to the use of pre-treatments on textural analysis (in Brazilian). Brazil J. Soil Sci., 27, 765-772.

Empresa Brasileira de Pesquisa Agropecuária - EMBRAPA, 1997. Manual of methods of soil analysis. National Soil Research Center, Rio de Janeiro, Brazil.

Empresa Brasileira de Pesquisa Agropecuária - EMBRAPA, 2013. Brazilian system of soil classification. National Soil Research Center, Rio de Janeiro, Brazil.

Fontana A., Pereira M.G., Anjos L.H.C., and Benites V.M., 2008. Distribution of organic carbon in the humic fractions of diagnostic horizons from Brazilian soils. Communications Soil Sci. Plant Analysis, 39, 7-8.

Hart R.D., Wiriyakitnatee kul W., and Gilkes R.J., 2003. Properties of soil kaolins from Thailand. Clay Mineral., 38, 71-94.

Hartge K.H. and Horn R., 2009 (Eds). The physical analysis of soils: practice, measurement methods, evaluation. Schweizerbart, Stuttgart, Germant, Germany.

Holtz R. and Kovacs W., 1981 (Eds). An Introduction to Geotechnical Engineering. Prentice Hall, Englewood Cliffs, NJ.

Horn R., Vossbrink J., and Becker S., 2004. Modern forest vehicles and their impacts on soil physical properties. Soil Till. Res., 79(2), 207-219.

Igwe C.A., 2005. Erodibility in relation to water-dispersible clay for some soils of eastern Nigeria. Land Degrad. Develop., $16,87-96$.

Igwe C.A. and Udegbunam O.N., 2008. Soil properties influencing water-dispersible clay and silt in an Ultisol in southern Nigeria. Int. Agrophysics, 22, 319-325.

Iori P., Dias Jr. M.S., Ajayi A.E., Guimarães P.T.G., Moreira Pais P.S., and Andrade M.L.C., 2013. Comparison of field and laboratory models of the load bearing capacity in coffee plantations. Ciência Agrotecnologia Lavras, 37(2), 130-137.

Jones R.J.A., Spoor G., and Thomason A.J., 2003. Vulnerability of subsoils in Europe to compaction: a preliminary analysis. Soil Till. Res., 73, 131-143.

Józfaciuk G., Sokołowska Z., Sokołowski S., Alekseev A., and Alekseeva T., 1995. Changes in mineralogical and surface properties of water dispersible clay after acid treatment of soils. Clay Minerals, 30, 149-155.

Kämpf N. and Schwertmann U., 1983. Goethite and hematite in a climosequence in southern Brazil and their application in classification of kaolinitic soils. Geoderma, 29(1), 27-39.
Ker J.C., 1997. Oxisols of Brazil: a review. Geonomos, 5, 17-40. Lehmann J., Skjemstad J., Sohi S., Carter J., Barson M., Falloon P., Coleman K., Woodbury P., and Krull E., 2008. Australian climate-carbon cycle feedback reduced by soil black carbon. Nature Geosci., 1, 832-835.

Martin D., Srivastava P.C., Ghosh D., and Zech W., 1998. Characteristics of humic substances in cultivated and natural forest soils of Sikkim. Geoderma, 84, 345-362.

Marques F.A., Calegari R.M., Torrado P.V., and Buurman P., 2011. Relationship between soil oxidizable carbon and physical, chemical and mineralogical properties of umbric ferralsols. Brazil J. Soil Sci., 35, 25-40.

Nguetnkam J.P. and Dultz S., 2011. Soil degradation in Central North Cameroon: Water-dispersible clay in relation to surface charge in Oxisol A and B horizons. Soil Till. Res., 113, $38-47$.

Novotny E.H., Bonagamba T.J., Azevedo E.R., and Hayes M.H.B., 2009. Solid-state $13 \mathrm{C}$ nuclear magnetic resonance characterization of humic acids extracted from Amazonian dark earths (Terra Preta de Índio). In: Amazonian dark earths: wim sombroek's vision (Eds W.I. Woods, W.G. Teixeira, J.Lehmann, C. Steiner, A. Winklerprins, L. Rebellato). Amsterdam, Springer, the Netherland.

Pais P.S.-M., Dias Jr., M.S., Dias A.C., Iori P., Guimarães P.T.G., and Santos G.A., 2013. Load-bearing capacity of a red-yellow latosol cultivated with coffee plants subjected to different weed managements. Ciência e Agrotecnologia, 37(2), 145-151.

Parfitt R.L., Theng B.K.G., Whitton J.S., Shepherd T.G., 1997. Effects of clay minerals and land use on organic matter pools. Geoderma, 75(1-2), 1-12.

Peng X.H., Horn R., Zhang B., and Zhaoa Q.G., 2004. Mechanisms of soil vulnerability to compaction of homogenized and recompacted Ultisols. Soil Till. Res., 76, 125-137.

Resende M., Curi N., Rezende S.B., Correa G.F., and Ker J.C., 2014. Pedology: basis for distinction of environments. Lavras, Editorial, UFLA, Brazil.

Römkens M.J.M. and Miller R.D., 1971. Predicting root size and frequency from one dimensional consolidation data A mathematical model. Plant Soil, 35(1-3), 237-248.

Schmidt M.W.I., Skjemstad J.O., Gehrt E., and KogelKnabner I., 1999. Charred organic carbon in German chernozemic soils. Europ. J. Soil Sci., 50, 351-365.

Schnitzer M., 1986. Binding of Humic Substances by Soil Mineral Colloids. In: Interactions of Soil Minerals with Natural Organics and Microbes (Eds P.M. Huang, M. Schnitzer). Soil Sci. Soc. America, Special Publication, 17, 77-101.

Severiano E.C., de Oliveira G.E., Dias Jr. M.S., Curi N., Costa K.A., and Carducci C.E., 2013. Preconsolidation pressure, soil water retention characteristics, and texture of Latosols in the Brazilian Cerrado. Soil Res., 51(3), 193-202.

Sherman G.D. and Alexander L.T., 1959. Characteristics and Genesis of Low Humic Latosols. Soil Sci. Soc. Am. J., 23, $168-170$

Shindo H., Honna T., Yamamoto S., and Honna H., 2004. Contribution of charred plant fragments to soil organic carbon in Japanese volcanic ash soils containing black humic acids. Org. Geochem., 35, 235-241. 
Silva A.C. and Vidal Torrado P., 1999. Genesis of Humic Oxisols and its relation to landscape evolution in a cratonic area of the south of Minas. Brazil J. Soil Sci., 23, 329-341.

Silva A.C., Vidal-Torrado P., González-Perez M., Martin Neto L., and Vasques F.M., 2007. Relationships between soil organic matter and slope steepness in toposequence of Oxisols in the south of Minas Gerais. Brazil J. Soil Sci., 31, 1059-1068.

Snedecor G.W. and Cochran W.G., 1989. Statical methods. Ames, Iowa State University, IA, USA.

Sutherland R.A. and Ziegler A.D., 1997. A new approach to determining water stable aggregation. Communications in Soil Sci. Plant Analysis, 28(19-20), 1871-1887.
Tawonpruek S., Kheoruenromne I., Suddhiprakarn A., and Gilkes R.J., 2006. Properties of red Oxisols on calcareous sedimentary rocks in Thailand. Geoderma, 136, 477-493.

Teh Boon Sung C., 2012. Aggregate stability of tropical soils in relation to their organic matter constituents and other soil properties. Pertanika J. Trop. Agric. Sci., 35(1), 135-148.

Tomasi A.C., Vasconcellos Inda A., and Dick D.P., 2012. Humic substances in highland subtropical Oxisol under different use and managements. Rural Sci., 42(12), 2180-2184.

Watson R.T., Noble I.R., Bolin B., Ravindramath N.H., Verardo D.J., and Dokken D.J., 2000. Land Use, LandUse Change, and Forestry (a special Report of the IPCC). Cambridge University Press, Cambridge, UK. 